38

The Open
Cardiovascular
lournal

RESEARCH ARTICLE

\title{
Severe Acute Respiratory Syndrome Coronavirus 2: The Importance of Prompt Detection of Cardiovascular Involvement
}

\author{
Osmar A. Centurión ${ }^{1,2, *}$, Luís M. Miño ${ }^{1,2}$ and Karina E. Scavenius ${ }^{1,2}$ \\ ${ }^{\prime}$ Department of Health Sciences's Investigation, Sanatorio Metropolitano, Fernando de la Mora, Paraguay \\ ${ }^{2}$ Department of Internal Medicine, Cardiology Department, Clinic Hospital, Asunción National University, San Lorenzo, Paraguay
}

\begin{abstract}
:
Increased morbidity and mortality are associated with coronavirus disease 2019 (COVID-19) when there is cardiovascular (CV) involvement. Due to the absence of prospective, well-designed, controlled studies, the exact mechanism responsible for cardiac injury among patients with COVID-19 remains uncertain. However, possible mechanisms described in observational studies can be considered. Non-ischemic events and ischemic myocardial involvement are the two main pathophysiological mechanisms of acute cardiac injury in COVID-19 patients. Non-ischemic myocardial injury is probably predominant and is secondary to multiple pathological mechanisms. Cardiac involvement is relatively common among hospitalized patients with COVID-19 and is associated with a greater risk of in-hospital mortality and ventricular arrhythmias. There was also a high and significantly positive linear correlation between troponin $\mathrm{T}$ and plasma high-sensitivity C-reactive protein levels. It is important to promptly detect CV involvement to avoid increased mortality in these patients. These findings highlight the importance of clinical surveillance and laboratory testing of serum troponin levels to ensure appropriate early identification and proceed with appropriate treatment. This should apply to patients with/without prior CV involvement. There are several possible mechanisms of myocardial tissue damage and the exact mechanisms involved need to be explored in well-designed studies.
\end{abstract}

Keywords: COVID-19, Cardiac Injury, Mortality, Inflammation, Myocarditis, C-reactive protein levels.

\begin{tabular}{|l|c|c|c|}
\hline Article History & Received: July 07, 2020 & Revised: October 03, 2020 & Accepted: October 20, 2020
\end{tabular}

Increased morbidity and mortality are associated with coronavirus disease 2019 (COVID-19) when there is cardiovascular (CV) involvement [1 - 5]. The publication of numerous articles regarding clinical outcomes has contributed to some understanding of several aspects of this novel disease, but COVID-19 is still relatively poorly understood [6 - 10]. This pandemic is caused by severe acute respiratory syndrome coronavirus 2 (SARS-CoV-2). Up till June 26, 2020, this disease resulted in considerable morbidity and mortality worldwide, with 9,473,214 laboratory-confirmed cases and 484,249 deaths [8]. There is increasing evidence of higher mortality risk associated with the presence of $\mathrm{CV}$ involvement in patients with COVID-19 [11 - 15].

SARS-CoV-2 appears to be easily transmittable, very contagious, and with higher morbidity and mortality in older patients and those at risk [14 - 19]. Therefore, clarification of the disease pathogenesis and prospective histopathological studies are relevant. The insight provided by histopathological

\footnotetext{
"Address correspondence to this author at Department of Health Sciences's Investigation, Asuncion National University, Sanatorio Metropolitano, Teniente Ettiene 215 c/ Ruta Mariscal Estigarribia, Fernando de la Mora, Paraguay; E-mail: osmarcenturion@hotmail.com
}

studies to better comprehend the diagnostic and therapeutic management in emerging diseases should be helpful. However, with the exception of a few case reports, it is interesting to note that with nearly half a million deaths, no prospective autopsy investigation has, to our knowledge, been reported so far.

Due to the absence of data based on prospective, welldesigned controlled studies, the exact mechanism of cardiac injury among patients with COVID-19 remains uncertain. However, different possible mechanisms described in observational studies can be considered [20 - 29]. Nonischemic events and ischemic myocardial involvement are the two main pathophysiological mechanisms of acute cardiac injury in COVID-19 patients [13]. It is believed that nonischemic myocardial injury is predominant and is secondary to multiple pathological mechanisms, namely, increased cytokine secretion and hypoxia-induced cardiac myocyte apoptosis.

Several observational studies reported the incidence of cardiac involvement in patients with COVID-19. Huang et al. [11] found that $12 \%$ of patients (5/41) with COVID-19 had associated acute cardiac injury. They observed myocardial inflammation in their patients by means of troponin I elevation and decreased cardiac ejection fraction in the echo- 
cardiography. Wang et al. [12] demonstrated that $7 \%$ of the patients, out of the total of 138 patients hospitalized with COVID-19, developed an acute cardiac injury. The patients in the intensive care unit (ICU) were more likely to develop cardiac involvement $(22 \%)$ than those who were not admitted to the ICU. Patients with known ischemic heart disease and cardiomyopathy were at higher risk. Higher mortality was seen when COVID-19 was associated with acute myocarditis, acute myocardial infarction, and rapid-onset heart failure [11]. This shows that $\mathrm{CV}$ involvement is associated with poor clinical outcomes of COVID-19.

Alhogbani [21] described the evidence from coronavirusassociated acute myocarditis, manifested as myocardial edema and acute myocardial injury assessed by cardiac magnetic resonance imaging. There is controversial evidence on the fact that this myocardial involvement may result from direct viral myocardial infection and inflammation. In a recent case report [27], there was scarce interstitial mononuclear inflammatory infiltrates assessed by histology in the myocardial tissue without substantial cardiac muscle tissue damage in a patient with COVID-19. Nevertheless, it was demonstrated that plasma troponin T levels were positively correlated $(\beta=0.530$, $P<0.001)$ in a significant manner with plasma high-sensitivity C-reactive protein (CRP) levels [15]. These findings indicate that myocardial injury may be associated with inflammatory pathogenesis during the progress of the disease. However, direct evidence demonstrating that SARS-CoV-2 infects the myocardial tissue or pericardial effusion liquid in patients with COVID-19 is currently lacking.

Another plausible mechanism of cardiac involvement implicates that the human cell receptor angiotensin-converting enzyme 2 (ACE2) has a strong binding affinity to the virus Spike protein of SARS-CoV-2. Since ACE2 is highly expressed in the heart, it is reasonable to hypothesize that COVID-19-induced cardiac injury might be mediated by ACE2 [22 - 26]. ACE2 is a key counter-regulatory enzyme that degrades angiotensin II to angiotensin-(1-7), thereby attenuating its effects on vasoconstriction, sodium retention, and fibrosis [30 - 33]. There are some inconsistent results in animal studies demonstrating the complexity of reninangiotensin-aldosterone system responses and emphasizing the notion that findings from experimental animal studies may not extrapolate to similar physiological responses in human subjects [34 - 37]. Indeed, basic studies performed in animals have shown mixed findings with respect to the effects of angiotensin-converting enzyme (ACE) inhibitor agents and angiotensin receptor blockade (ARB) on ACE2 levels or activity in different tissues [34 - 44]. Some studies have shown that ARB may increase messenger RNA expression or protein levels of ACE2 in tissue [34, 40], while other studies demonstrated no effect [37]. This shows the importance, relevance, and necessity of human studies to shed more light on this system. The drug-induced increased ACE2 expression produced by ACE inhibitors or ARB might aggravate lung injury of patients with COVID-19. However, the beneficial effect of ACE inhibitors was demonstrated in patients with viral pneumonia [41]. In 1055 adult study patients, with a positive polymerase chain reaction test for different types of viral pneumonia, there were lower rates of death and intubation in those patients with continued use of ACE inhibitors, and also a significant reduction in the pulmonary inflammatory response and cytokine release caused by virus infection was observed [41]. Similar beneficial findings were shown in another study that demonstrated a significant decrease in mortality, length of stay, and mechanical ventilation in patients taking ACE inhibitors or ARB, who were hospitalized with pneumonia and compared with a matching cohort [42]. The beneficial effects of ACE inhibitors and ARB may be related to a compensatory increase in ACE2 by their attenuating effects on the ACE2 downregulation produced by the binding of SARS-CoV Spike protein to ACE2 in the lungs and other organs [28, 44]. However, the evidence regarding their utilization in patients with COVID-19 infection is still emerging, and larger, prospective, randomized, clinical studies are required to produce definitive answers. At present, for patients with COVID-19 who previously used ACE inhibitors or ARB, their utilization may not need to be discontinued based on current data.

Another possible mechanism involved in cardiac injury may be the increased cytokine secretion during COVID-19. In a study of 46 patients, a significantly higher left ventricular index of myocardial performance, longer isovolumic relaxation time, lower flow propagation velocity, and Doppler-derived cardiac output was shown during the acute infection when compared with those at 30 days. It was suggested that left ventricular dysfunction in the acute phase of the disease might be attributable to the cytokine storm syndrome, resulting from an overaggressive host immune response to SARS-CoV infection [28]. In another study [11], severely ill patients with COVID-19 who were admitted to the ICU had higher plasma levels of cytokines, including interleukin (IL)-2, IL-7, IL-10, granulocyte-colony stimulating factor, and IgG-induced protein 10. They also had higher plasma levels of monocyte chemoattractant protein-1, macrophage inflammatory protein 1 -alpha, and tumor necrosis factor $\alpha$. Some other markers of the inflammatory response, such as CRP, procalcitonin, and leukocytes, were also found to be significantly increased among patients who suffered from cardiac injury [11]. The storming activation and secretion of these inflammatory cytokines can lead to apoptosis or necrosis of myocardial cells in COVID-19 [11 - 13].

Another interesting possible mechanism of cardiac injury is the altered myocardial demand/supply ratio in association with increased cardio-metabolic demand in the myocardial tissue, which can result in myocyte hypoxia [26]. This alteration, in the context of systemic inflammation, associated with acute respiratory illness-related hypoxia, can further impair myocardial oxygen demand/supply relationship and lead to acute myocardial injury [26]. In addition, the endothelial dysfunction developed in systemic inflammation and the increment in pro-coagulant activity [29] of the blood can further contribute to thrombosis over a ruptured coronary plaque. The intrinsic inflammatory process within the atherosclerotic coronary plaques is exacerbated during the systemic inflammatory response in patients with COVID-19, making them susceptible to fissure, initiating an acute myocardial infarct [29]. 
Several observational studies reported evidence of higher morbidity and mortality risk associated with the findings of inflammation and $\mathrm{CV}$ involvement and especially cardiac injury in patients with COVID-19. Shi et al. [13] were the first to report that cardiac injury was independently associated with an increased risk of mortality in COVID-19. They showed that cardiac involvement is relatively common among hospitalized patients with COVID-19 and that it is associated with a higher risk of in-hospital mortality and ventricular arrhythmias [13]. These findings highlight the importance of clinical surveillance and laboratory testing of serum troponin levels to establish early identification of atypical cases with an acute illness of COVID-19 and proceed with appropriate treatment. A metaanalysis [43] that included 341 patients with severe COVID-19 found that troponin I plasma values were significantly increased. Therefore, it seems rational to assume that initial measurements of serum biomarkers of cardiac injury should be performed immediately after hospitalization for COVID-19 patients, and further in-hospital monitoring may help to identify a subset of severe cases with possible cardiac involvement and consequently predict a worse clinical scenario.

\section{CONCLUSION}

In conclusion, it is paramount to promptly detect $\mathrm{CV}$ involvement since mortality increases with cardiac injury in COVID-19. Myocardial injury was found to be related to cardiac dysfunction, ventricular arrhythmias, and it was independently associated with an increased risk of morbidity and mortality in patients with COVID-19. There was a high and significantly positive linear correlation between troponin $\mathrm{T}$ and plasma high-sensitivity CRP levels. The exact mechanism of cardiac injury needs to be further explored in well-designed studies.

\section{CONFLICT OF INTEREST}

The authors declare no conflict of interest, financial or otherwise.

\section{ACKNOWLEDGEMENTS}

Declared none.

\section{REFERENCES}

[1] Mali SN, Thorat BR, Chopade AR. A viewpoint on angiotensinconverting enzyme 2, anti-hypertensives and coronavirus disease 2019 (COVID-19). Infect Disord Drug Targets 2020.

[http://dx.doi.org/10.2174/1871526520666200511005546] [PMID: 32389117]

[2] Thomson B. The COVID-19 pandemic: a global natural experiment. Circulation 2020; 142(1): 14-6.

[http://dx.doi.org/10.1161/CIRCULATIONAHA.120.047538] [PMID: 32324429]

[3] Kim JY, Choe PG, Oh Y, et al. The first case of 2019 novel coronavirus pneumonia imported into Korea from Wuhan, China: implication for infection prevention and control measures. J Korean Med Sci 2020; 35(5)e61

[http://dx.doi.org/10.3346/jkms.2020.35.e61] [PMID: 32030925]

[4] Madjid M, Safavi-Naeini P, Solomon SD, Vardeny O. Potential effects of coronaviruses on the cardiovascular system: A review. JAMA Cardiol 2020; 5(7): 831-40.

[http://dx.doi.org/10.1001/jamacardio.2020.1286] [PMID: 32219363]

[5] Maisch B, Portig I, Ristic A, Hufnagel G, Pankuweit S. Definition of inflammatory cardiomyopathy (myocarditis): on the way to consensus.
A status report. Herz 2000; 25(3): 200-9.

[http://dx.doi.org/10.1007/s000590050007] [PMID: 10904839]

[6] Xiong TY, Redwood S, Prendergast B, Chen M. Coronaviruses and the cardiovascular system: acute and long-term implications. Eur Heart J 2020; 41(19): 1798-800.

[PMID: 32186331]

[7] Bonow RO, Fonarow GC, O'Gara PT, Yancy CW. Association of coronavirus disease 2019 (COVID-19) with myocardial injury and mortality. JAMA Cardiol 2020; 5(7): 751-3.

[PMID: 32219362]

[8] World Health Organization (WHO) Coronavirus Disease https://covid19.who.int/?gclid=EAIaIQobChMIqq3etdTe6gIVkwqRCh 02awzgEAAYASAAEgJf2fD_BwE

[9] $\mathrm{Hu} \mathrm{H}, \mathrm{Ma} F$, Wei X, Fang Y. Coronavirus fulminant myocarditis saved with glucocorticoid and human immunoglobulin. Eur Heart $\mathrm{J}$ 2020; ehaa190.

[http://dx.doi.org/10.1093/eurheartj/ehaa190] [PMID: 32176300]

[10] Centurión OA, Scavenius KE, García LB, Torales JM, Miño LM. Potential mechanisms of cardiac injury and common pathways of inflammation in patients with COVID-19. Crit Pathw Cardiol 2020. [http://dx.doi.org/10.1097/HPC.0000000000000227] [PMID: 32467423]

[11] Huang C, Wang Y, Li X, et al. Clinical features of patients infected with 2019 novel coronavirus in Wuhan, China. Lancet 2020; 395(10223): 497-506.

[http://dx.doi.org/10.1016/S0140-6736(20)30183-5]

[PMID: 31986264]

[12] Wang D, Hu B, Hu C, et al. Clinical characteristics of 138 hospitalized patients with 2019 novel coronavirus-infected pneumonia in Wuhan, China. JAMA 2020; 323(11): 1061-9.

[http://dx.doi.org/10.1001/jama.2020.1585] [PMID: 32031570]

[13] Shi S, Qin M, Shen B, Cai Y, Liu T, Yang F. Association of cardiac injury with mortality in hospitalized patients with covid-19 inwuhan, china. JAMA Cardiol 2020; (March): 25.

[http://dx.doi.org/10.1001/jamacardio.2020.0950] [PMID: 32211816]

[14] Wu Z, McGoogan JM. Characteristics of and important lessons from the coronavirus disease 2019 (COVID-19) outbreak in china: Summary of a report of 72314 cases from the chinese center for disease control and prevention. JAMA 2020; 323(13): 1239-42. [http://dx.doi.org/10.1001/jama.2020.2648] [PMID: 32091533]

[15] Guo T, Fan Y, Chen M, et al. Cardiovascular implications of fatal outcomes of patients with coronavirus disease 2019 (COVID-19). JAMA Cardiol 2020; 5(7): 811-8.

[http://dx.doi.org/10.1001/jamacardio.2020.1017] [PMID: 32219356]

[16] de Wit E, van Doremalen N, Falzarano D, Munster VJ. SARS and MERS: Recent insights into emerging coronaviruses. Nat Rev Microbiol 2016; 14(8): 523-34.

[http://dx.doi.org/10.1038/nrmicro.2016.81] [PMID: 27344959]

[17] Yin Y, Wunderink RG. MERS, SARS and other coronaviruses as causes of pneumonia. Respirology 2018; 23(2): 130-7. [http://dx.doi.org/10.1111/resp.13196] [PMID: 29052924]

[18] Song Z, Xu Y, Bao L, et al. From SARS to MERS, thrusting coronaviruses into the spotlight. Viruses 2019; 11(1)E59 [http://dx.doi.org/10.3390/v11010059] [PMID: 30646565]

[19] Chen N, Zhou M, Dong X, et al. Epidemiological and clinical characteristics of 99 cases of 2019 novel coronavirus pneumonia in Wuhan, China: a descriptive study. Lancet 2020; 395(10223): 507-13. [http://dx.doi.org/10.1016/S0140-6736(20)30211-7]

[PMID: 32007143]

[20] Yu CM, Wong RS, Wu EB, et al. Cardiovascular complications of severe acute respiratory syndrome. Postgrad Med J 2006; 82(964): $140-4$.

[http://dx.doi.org/10.1136/pgmj.2005.037515] [PMID: 16461478]

[21] Alhogbani T. Acute myocarditis associated with novel Middle east respiratory syndrome coronavirus. Ann Saudi Med 2016; 36(1): 78-80. [http://dx.doi.org/10.5144/0256-4947.2016.78] [PMID: 26922692]

[22] Wrapp D, Wang N, Corbett KS, et al. Cryo-EM structure of the 2019nCoV spike in the prefusion conformation. Science 2020; 367(6483): 1260-3.

[http://dx.doi.org/10.1126/science.abb2507] [PMID: 32075877]

[23] Bourgonje AR, Abdulle AE, Timens W, et al. Angiotensin-converting enzyme 2 (ACE2), SARS-CoV-2 and the pathophysiology of coronavirus disease 2019 (COVID-19). J Pathol 2020; 251(3): 228-48. [http://dx.doi.org/10.1002/path.5471] [PMID: 32418199]

[24] Patel VB, Zhong JC, Grant MB, Oudit GY. Role of the ace2/angiotensin 1-7 axis of the renin-angiotensin system in heart failure. Circ Res 2016; 118(8): 1313-26. 
[http://dx.doi.org/10.1161/CIRCRESAHA.116.307708] [PMID: 27081112]

[25] Li W, Moore MJ, Vasilieva N, et al. Angiotensin-converting enzyme 2 is a functional receptor for the SARS coronavirus. Nature 2003; 426(6965): 450-4.

[http://dx.doi.org/10.1038/nature02145] [PMID: 14647384]

[26] Padro T, Manfrini O, Bugiardini R, et al. ESC Working Group on Coronary Pathophysiology and Microcirculation position paper on 'coronary microvascular dysfunction in cardiovascular disease'. Cardiovasc Res 2020; 116(4): 741-55.

[http://dx.doi.org/10.1093/cvr/cvaa003] [PMID: 32034397]

[27] Xu Z, Shi L, Wang Y, et al. Pathological findings of COVID-19 associated with acute respiratory distress syndrome. Lancet Respir Med 2020; 8(4): 420-2.

[http://dx.doi.org/10.1016/S2213-2600(20)30076-X] [PMID: 32085846]

[28] Li SS, Cheng CW, Fu CL, et al. Left ventricular performance in patients with severe acute respiratory syndrome: a 30-day echocardiographic follow-up study. Circulation 2003; 108(15): 1798-803.

[http://dx.doi.org/10.1161/01.CIR.0000094737.21775.32] [PMID: 14504188]

[29] Tersalvi G, Vicenzi M, Calabretta D, Biasco L, Pedrazzini G, Winterton D. Elevated troponin in patients with Coronavirus Disease 2019 (COVID-19): possible mechanisms. J Card Fail 2020; 26(6): 470-5.

[http://dx.doi.org/10.1016/j.cardfail.2020.04.009] [PMID: 32315733]

[30] Vickers C, Hales P, Kaushik V, et al. Hydrolysis of biological peptides by human angiotensin-converting enzyme-related carboxypeptidase. J Biol Chem 2002; 277(17): 14838-43. [http://dx.doi.org/10.1074/jbc.M200581200] [PMID: 11815627]

[31] Hamming I, Timens W, Bulthuis MLC, Lely AT, Navis G, van Goor H. Tissue distribution of ACE2 protein, the functional receptor for SARS coronavirus. A first step in understanding SARS pathogenesis. J Pathol 2004; 203(2): 631-7.

[http://dx.doi.org/10.1002/path.1570] [PMID: 15141377]

[32] Serfozo P, Wysocki J, Gulua G, et al. Ang II (angiotensin II) conversion to angiotensin-(1-7) in the circulation is POP (prolyloligopeptidase)-dependent and ACE2 (angiotensin-converting enzyme 2)-independent. Hypertension 2020; 75(1): 173-82.

[http://dx.doi.org/10.1161/HYPERTENSIONAHA.119.14071] [PMID: 31786979]

[33] Rice GI, Thomas DA, Grant PJ, Turner AJ, Hooper NM. Evaluation of angiotensin-converting enzyme (ACE), its homologue ACE2 and neprilysin in angiotensin peptide metabolism. Biochem J 2004; 383(Pt 1): 45-51.

[http://dx.doi.org/10.1042/BJ20040634] [PMID: 15283675]

[34] Ferrario CM, Jessup J, Chappell MC, et al. Effect of angiotensinconverting enzyme inhibition and angiotensin II receptor blockers on cardiac angiotensin-converting enzyme 2. Circulation 2005; 111(20):
2605-10.

[http://dx.doi.org/10.1161/CIRCULATIONAHA.104.510461] [PMID: 15897343]

[35] Ocaranza MP, Godoy I, Jalil JE, et al. Enalapril attenuates downregulation of Angiotensin-converting enzyme 2 in the late phase of ventricular dysfunction in myocardial infarcted rat. Hypertension 2006; 48(4): 572-8.

[http://dx.doi.org/10.1161/01.HYP.0000237862.94083.45] [PMID: 16908757]

[36] Hamming I, van Goor H, Turner AJ, et al. Differential regulation of renal angiotensin-converting enzyme (ACE) and ACE2 during ACE inhibition and dietary sodium restriction in healthy rats. Exp Physiol 2008; 93(5): 631-8.

[http://dx.doi.org/10.1113/expphysiol.2007.041855]

[PMID: 18192334]

[37] Burrell LM, Risvanis J, Kubota E, et al. Myocardial infarction increases ACE2 expression in rat and humans. Eur Heart J 2005; 26(4): 369-75.

[http://dx.doi.org/10.1093/eurheartj/ehi114] [PMID: 15671045]

[38] Gonzalez-Jaramillo N, Low N, Franco OH. The double burden of disease of COVID-19 in cardiovascular patients: overlapping conditions could lead to overlapping treatments. Eur J Epidemiol 2020; 35(4): 335-7.

[http://dx.doi.org/10.1007/s10654-020-00628-1] [PMID: 32296994]

[39] Vuille-dit-Bille RN, Camargo SM, Emmenegger L, et al. Human intestine luminal ACE2 and amino acid transporter expression increased by ACE-inhibitors. Amino Acids 2015; 47(4): 693-705. [http://dx.doi.org/10.1007/s00726-014-1889-6] [PMID: 25534429]

[40] Soler MJ, Ye M, Wysocki J, William J, Lloveras J, Batlle D. Localization of ACE2 in the renal vasculature: amplification by angiotensin II type 1 receptor blockade using telmisartan. Am J Physiol Renal Physiol 2009; 296(2): F398-405.

[PMID: 19004932]

[41] Henry C, Zaizafoun M, Stock E, Ghamande S, Arroliga AC, White HD. Impact of angiotensin-converting enzyme inhibitors and statins on viral pneumonia. Proc Bayl Univ Med Cent 2018; 31(4): 419-23. [PMID: 30948970]

[42] Mortensen EM, Nakashima B, Cornell J, et al. Population-based study of statins, angiotensin II receptor blockers, and angiotensin-converting enzyme inhibitors on pneumonia-related outcomes. Clin Infect Dis 2012; 55(11): 1466-73.

[http://dx.doi.org/10.1093/cid/cis733] [PMID: 22918991]

[43] Lippi G, Lavie CJ, Sanchis-Gomar F. Cardiac troponin in COVID-2019. Prog Cardiovasc Dis 2020.

[http://dx.doi.org/10.1016/j.pcad.2020.03.001] [PMID: 32169400]

[44] Kuba K, Imai Y, Rao S, et al. A crucial role of angiotensin converting enzyme 2 (ACE2) in SARS coronavirus-induced lung injury. Nat Med 2005; 11(8): 875-9.

[http://dx.doi.org/10.1038/nm1267] [PMID: 16007097]

\section{C) 2020 Centurión et al.}

This is an open access article distributed under the terms of the Creative Commons Attribution 4.0 International Public License (CC-BY 4.0), a copy of which is available at: https://creativecommons.org/licenses/by/4.0/legalcode. This license permits unrestricted use, distribution, and reproduction in any medium, provided the original author and source are credited. 